\title{
Identification of subclinical mastitis caused by Mycoplasma spp. from screenings of bulk tanks
}

[Identificação de mastite subclínica causada por Mycoplasma spp. de triagem de tanques de expansão ]

\author{
S.F. Joaquim, F.F. Guimarães, A. Salina, N.B. Junqueira, E.N. Gomes, H. Langoni
}

Universidade Estadual Paulista - Botucatu, SP

\begin{abstract}
Mastitis caused by Mycoplasma spp., regardless of species, are considered highly contagious pathogens and, usually was not responsive to antimicrobial therapy. Five dairy herds, comprising 489 animals and 1,956 mammary glands, were used in this study. Milk samples were obtained from bulk tanks and subjected to polymerase chain reaction (PCR) for the identification of Mollicutes, Mycoplasma spp., and Mycoplasma bovis. Moreover, individual samples from cases of clinical and subclinical mastitis in quarters of the dairy herds' animals that yielded a positive PCR upon bulk tank analysis were subjected to molecular analysis. Only one bulk tank was positive for class Mollicutes by PCR. All positive samples classified as mastitis teats had their DNA extracted and tested by PCR for both class Mollicutes and M. bovis. Of these, two (2.08\%) were positive for Mycoplasma genus, although none was positive for $M$. bovis. This result suggests that the PCR of bulk tanks is a viable tool in monitoring and preventing mastitis infections caused by Mycoplasma spp.
\end{abstract}

Keywords: milk quality, polymerase chain reaction, dairy herds

\section{RESUMO}

Mastites bovinas causadas por Mycoplasma spp., independentemente da espécie causadora, são consideradas de alta contagiosidade e geralmente não responsivas à terapia antimicrobiana. Cinco propriedades leiteiras foram utilizadas neste estudo, totalizando 489 animais e 1956 quartos mamários. As amostras de leite foram obtidas de tanques de expansão e submetidas à reação em cadeia da polimerase (PCR) para pesquisa de Mollicutes, Mycoplasma spp. e Mycoplasma bovis. Apenas um tanque de uma propriedade foi positivo na PCR para a classe Mollicutes. Amostras individuais de casos de mastite subclínica provenientes de propriedade com tanque positivo também foram submetidas à análise molecular; dessas, duas delas (2,08\%) foram positivas para a classe Mollicutes e para o gênero Mycoplasma, entretanto nenhuma foi positiva para a espécie Mycoplasma bovis. Isso sugere que a PCR de tanques de expansão de propriedades leiteiras demonstra ser uma ferramenta viável no monitoramento e na prevenção de infecções por Mycoplasma spp.

Palavras-chave: qualidade do leite, reação em cadeia da polimerase, rebanhos leiteiros

\section{INTRODUCTION}

Mycoplasma spp. are considered highly contagious pathogens that cause bovine mastitis. The transmission of these pathogens occurs primarily during the milking period (Fox and Gay, 1993). These microorganisms are considered a worldwide problem (House et al., 2011).

Recebido em 5 de maio de 2017

Aceito em 3 de fevereiro de 2018

E-mail: sameajoaquim@gmail.com
Among the species of Mycoplasma, M. bovis is responsible for most mastitis outbreaks in dairy herds. Cows at any age and stage of lactation, including the non-lactating stage, are susceptible (Fox, 2012) to an intramammary infection by Mycoplasma spp., with ranging degrees of severity of disease. 
Mastitis caused by Mycoplasma spp., regardless of the specific species, usually is not responsive to treatment with antibiotics (Owens and Nipper, 2008). Being a highly contagious microorganism, Mycoplasma spp. can be disseminated as an aerosol or through secretions by animals with respiratory and genital disorders and during milking. The hematogenous or lymphatic pathways are responsible for the bacterium's spread from one organ to another (Bennett and Jasper, 1977). The milk obtained from an animal with Mycoplasma spp. mastitis may be brownish to brown and, when allowed to settle, can have the appearance of sandy granules (Kirk et al., 1994).

The literature reports an incidence of $0.5-35 \%$ of Mycoplasma bovis (M. bovis) as an agent of bovine mastitis in several countries (González and Wilson, 2003). There are few reports of mastitis caused by $M$. bovis in Brazil. The first mention of mastitis by this agent was made by Mettifogo et al. (1996) at Londrina, Paraná, in the southern region of the country. Additionally, Pretto et al. (2001), working with 713 dairy cows from three dairy herds in northern Parana and southwest of the State of São Paulo, diagnosed 137 cows with mastitis; eight $(1.12 \%)$ of these infections were caused by $M$. bovis.

The low incidences of $M$. bovis mastitis could be related to the difficulty in diagnosis; isolation of Mycoplasma spp. requires special broth, different incubation times, and micro-aerophilic conditions. The Mycoplasma cultivation may be compromised even in ideal conditions. The type of clinical sample, the method of collection and transportation, the pathogen's nutritional requirements, and the number of viable Mycoplasma in the clinical material may interfere with the results (Buzinhani et al., 2007).

In order to reduce the loss of production and maintain milk quality, isolating and characterizing the causative agent(s) of mastitis are essential. In Brazil, cultures for isolation of Mycoplasma spp. are not routinely performed, which would be an important tool to assess the actual involvement of Mycoplasma spp. in mastitis. Thus, the objective of this study was to evaluate the occurrence of clinical and subclinical mastitis in dairy farms, characterize the pathogens involved in these cases, and use molecular techniques to detect Mycoplasma spp. in bulk tanks and in each animal with mastitis from a positive herd.

\section{MATERIAL AND METHODS}

Five dairy herds for convenience were used, each with a mechanized milking system and a minimum of 50 lactating cows, regardless of race, stage of lactation, and age of animal, totaling 489 animals and 1,956 teats.

The following screen tests were performed: strip cup test for identification of clinical mastitis cases and Californian Mastitis Test (CMT) for detection of subclinical mastitis cases (Schalm and Noorlander, 1957).

Duplicate milk samples were aseptically collected from all mammary glands that tested positive on the screening tests for microbiological examination. Samples were also obtained from bulk tanks of the dairy herds sampled. The samples were transported to the laboratory under refrigerated temperatures in an isothermal container with recyclable ice.

Conventional microbiological culture was performed for all samples in bovine blood agar (5\%) and MacConkey broth with incubation for 72 hours and observation of microbial growth every 24 hours for 3 days to identify the etiological agents involved in the mastitis cases. The samples were considered contaminated when more than 2 types of colonies were isolated from a sample (Laboratory..., 1999).

The samples obtained from the bulk tanks were subjected to polymerase chain reaction (PCR) to search for Mollicutes. From the dairy herds that had bulk tanks with positive samples, all the animals with mastitis cases were sampled, and their milk was subjected to DNA extraction and PCR. Subsequently, these samples from individual animals were tested for Mycoplasma spp. and M. bovis.

The extraction of nucleic acids from samples from bulk tanks of the dairy herds was carried out using the commercial blood genomic Prep Mini Spin Kit (GE Healthcare $®)$ following the manufacturer's protocol.

Amplification of Mollicutes DNA was
performed using MGSO primers


TGCACCATCTGTCACTCTGTTAACCTC-3')
and GPO-3 GGGAGCAAACAGGATTAGATACCCT-3')

(Van Kuppeveld et al., 1992); samples were heated to $94^{\circ} \mathrm{C}$ for five minutes, then subjected to thirty-five cycles of $94^{\circ} \mathrm{C}$ for 30 seconds, $55^{\circ} \mathrm{C}$ for 30 seconds, and $72^{\circ} \mathrm{C}$ for 30 seconds, followed by a final extension at $72^{\circ} \mathrm{C}$ for 10 minutes, with the amplified product being 270 base pairs.

For detection of Mycoplasma spp., one nestedPCR was performed as described by Harasawa (1996) using the external primers F1 (5'ACACCATGGAG (C/T) TGGTAAT-3') and R1 $\begin{array}{llll}\left(5^{\prime}-\mathrm{CTTC}\right. & (\mathrm{A} / \mathrm{T}) & \mathrm{TCGACTT} & (\mathrm{C} / \mathrm{T})\end{array}$ CAGACCCAAGGCAT-3') and internal primers F2 (5'-GTG (C/G) GG (A/C) TGGATCACCTCCT- $\left.3^{\prime}\right)$ and R2 (5'GCATCCACCA (A/T) (A/T) AC (T/C) CTT-3'). The cycling profile used was initial denaturation at $94^{\circ} \mathrm{C}$ for 30 seconds, followed by 30 cycles of $94^{\circ} \mathrm{C}$ for 30 seconds, $55^{\circ} \mathrm{C}$ for 2 minutes, and $72^{\circ} \mathrm{C}$ for 2 minutes, with a final extension at $72^{\circ} \mathrm{C}$ for 5 minutes. The individual samples positive for the genus Mycoplasma were subjected to another PCR for $M$. bovis identification and the following primers were used: MBOR (5'CCGTCACATAGGTAGTTCATCT-3') and MBOF

CCTGGATTTAGAGTTTAGCGGATG-3')

(González et al., 1995); initial denaturation was performed at $93^{\circ} \mathrm{C}$ for three minutes, followed by thirty-five cycles of $94^{\circ} \mathrm{C}$ for one minute, $60^{\circ} \mathrm{C}$ for one minute, and $72^{\circ} \mathrm{C}$ for one minute, with a final extension of $72^{\circ} \mathrm{C}$ for three minutes, with the amplified product being 360 base pairs.
PCR was performed in a total volume of $25 \mu \mathrm{L}$, containing $10 \mathrm{mM}$ Tris- $\mathrm{HCl}$ buffer at $\mathrm{pH} 8.0$, $50 \mathrm{mM} \mathrm{KCl}, 1.5 \mathrm{mM} \mathrm{MgCl}{ }_{2}, 0.2 \mathrm{mM}$ dNTP, $10 \mathrm{pm}$ of each primer, 0.5 units of Taq Platinum (Invitrogen), and 10ng of DNA. Incubations were performed in a MasterCycler Gradient Thermocycler (Eppendorf).

Visualization of amplified products was performed by agarose gel electrophoresis using a $1.5 \%$ agarose gel containing Nancy-520 (Sigma Life Science). The electrophoretic run was performed in a horizontal vat containing $1 \mathrm{X}$ TBE (89mM Tris- $\mathrm{HCl}, 89 \mathrm{mM}$ boric acid, and $20 \mathrm{mM}$ EDTA); the voltage applied was $80 \mathrm{~V}$ for 60 minutes. Gels were visualized in a UV light transilluminator, and the image was captured by a digital documentation system.

Absolute and relative frequencies of the different categorical variables were calculated from the CMT and microbiological culture. The chisquare test was conducted to evaluate if the prevalence of subclinical mastitis was different between dairy herds (a p-value $<0.05$ was considered significant).

This research project was approved by "Comissão de Ética no Uso de Animais (CEUA) FMVZ - UNESP / Botucatu, SP" with the protocol number 229/2012.

\section{RESULTS}

Among the 1,956 teats analyzed, 440 were positive in the CMT (Table 1).

Table 1. Profile of bovine teats analyzed from five dairy herds at São Paulo State, 2017

\begin{tabular}{ccccccccc}
$\begin{array}{c}\text { Negativ } \\
\text { e by } \\
\text { CMT }\end{array}$ & Positive by CMT & & $\begin{array}{c}\text { al } \\
\text { mastiti } \\
\mathrm{s}\end{array}$ & Lost & $\begin{array}{c}\text { In } \\
\text { colostru } \\
\mathrm{m}\end{array}$ & $\begin{array}{c}\text { In } \\
\text { treatment }\end{array}$ & Total \\
\hline $\begin{array}{c}1448 \\
(74.08 \\
\%)\end{array}$ & $1+$ & $2+$ & $3+$ & 19 & 40 & 7 & $2(0.10 \%)$ & 1956 \\
\hline
\end{tabular}

The dairy farm properties were numbered from 1 to 5. Dairy farm number 1 had $96(20.17 \%)$ positive teats by CMT, while number 2 had 175
(18.8\%). The properties number 3,4 , and 5 had $62(35.03 \%), 75(46.58 \%)$, and $32(22.38 \%)$, respectively. 
Based on the chi-square test, the occurrence of subclinical mastitis did differ between the dairy herds; the probability that the proportion of positive cows did not differ between farms is $<0.0001 \%$.

Only the bulk tank from dairy herd number 1 was positive for Mollicutes by PCR. All positive samples in the CMT had their DNA extracted and tested by PCR for both Mollicutes and $M$. bovis; two were positive for Mycoplasma genus $(2.08 \%)$, but neither was positive for $M$. bovis.

\section{DISCUSSION}

Microorganisms of the genus Mycoplasma are widely distributed, but the special conditions necessary for diagnosis are a barrier to research on this etiological agent of mastitis. Mycoplasma spp. infections are highly contagious, and prompt diagnosis of this kind of intramammary infection is required. One of the best options, therefore, is diagnostic PCR, as the result can be obtained a few hours after sample arrival. In addition, PCR can provide higher sensitivity $(96.2 \%)$ and specificity (99.1\%) compared to a microbiological culture (Baird et al., 1999).

Previous studies using molecular techniques for diagnosis have shown low prevalence of bovine mastitis caused by Mycoplasma spp., such as $2.08 \%$ found in this study, $8.2 \%$ in Greece (Filioussis et al., 2007), and 2.4\% in Switzerland (Aebi et al., 2015). Research conducted in Brazil also showed similar results when either herds or mammary quarters were evaluated. The low prevalence of Mycoplasma spp. mastitis detected in the present study corroborated those obtained by other Brazilian authors (Francheschini et al., 2006; Mettifogo et al., 1996; Pretto et al., 2001).

PCR is a rapid and effective method to identify mastitis cases caused by Mycoplasma spp., but several species of this genus can be responsible for the infection, such as $M$. alkalescens, $M$. bovigenitalium, $M$. californicum, and $M$. Canadian (González and Wilson, 2003); however, $M$. bovis is responsible for most bovine mastitis outbreaks. This fact can explain the limitation of this study that although the diagnose of Mycoplasma spp. have been done in the bulk tank and the quarter infected, it was not possible to identify the specie causing mastitis.
Studies suggested that there is greater risk of mastitis caused by Mycoplasma spp. in larger herds, which may be due to the constant introduction of new animals (McCluskey et al., 2003). Keeping that in mind, the dairy herds chosen in this study have at least 50 dairy cows. In addition to the herd size, other factors contributing to mastitis are linked to the presence of microorganisms in dairy farms, such as the dry period of the cows, during which this pathogen can remain in the dry cows, feeding calves with contaminated milk, and close contact of lactating cows with calves through nasal secretions (Nicholas et al., 2016).

The monitoring of bulk tanks can be used to avoid Mycoplasma mastitis outbreaks (Passchyn et al., 2012). The isolation of Mycoplasma spp. from bulk tanks may vary in different countries; the incidence of Mycoplasma spp. in France was reported to be less than 1\% (Arcangioli et al., 2012), $1.5 \%$ in Belgium (Passchyn et al., 2012) and $5.4 \%$ in Greece (Filioussis et al., 2007).

\section{CONCLUSION}

Despite the fact that the prevalence of Mycoplasma spp. as an agent of mastitis was low in the studied region, PCR testing of the bulk tanks was shown to be a viable tool in monitoring and preventing mastitis infection from this etiologic origin.

\section{ACKNOWLEDGEMENTS}

This study was funded by FAPESP (The São Paulo Research Foundation) scholarship grant number 2011/14135-0.

\section{REFERENCES}

AEBI, M.; BORNE, B.H.; RAEMY, A.; STEINER, A.; PILO, P.; BODMER, M. Mycoplasma bovis infections in Swiss dairy cattle : a clinical investigation. Acta Vet. Scand., v.57, p.1-11, 2015.

ARCANGIOLI, M.A.; ASLAN, H.; TARDY, F.; POUMARAT, F.; LE GRAND, D. The use of pulsed-field gel electrophoresis to investigate the epidemiology of Mycoplasma bovis in French calf feedlots. Vet. J., v.192, p.96-100, 2012. 
BAIRD, S.C.; CARMAN, J.; DINSMORE, R.P.; WALKER, R.L.; COLLINS, J.K. Detection and identification of Mycoplasma from bovine mastitis infections using a nested polymerase chain reaction. J. Vet. Diagn. Invest., v.11, p.432-435, 1999.

BENNETT, R.H.; JASPER, D.E. Immunosuppression of humoral and cellmediated responses in calves associated wtih inoculation of Mycoplasma bovis. Am. J. Vet. Res., v.38, p.1731-1738, 1977.

BUZINHANI, M.; METIFFOGO, E.; TIMENETSKY, J. Detecção de Mycoplasma spp. e ureaplasma diversum em vacas com distúrbios reprodutivos. Arq. Bras. Med. Vet. Zootec, v.59, p.1368-1375, 2007.

FILIOUSSIS, G.; CHRISTODOULOPOULOS, G.; THATCHER, A.; PETRIDOU, V.; BOURTZI-CHATZOPOULOU, E. Isolation of Mycoplasma bovis from bovine clinical mastitis cases in Northern Greece. Vet., J, v.173, p.215$218,2007$.

FOX, L.; GAY, J.M. Contagious mastitis. Vet. Clin. N. Am. Food A, v.9, p.475-487, 1993.

FOX, L.K. Mycoplasma mastitis. Vet. Clin. Food Anim. Pract., v.28, p.225-237, 2012.

FRANCHESCHINI, V.; NOGUEIRA, M.; VICTORIA, C.; SILVA, R.; LANGONI, H. Research for Mycoplasma spp. in milk samples from mastitic cows. Ars Vet., v.22, p.130-134, 2006.

GONZÁLEZ, R.N.; WILSON, D.J. Mycoplasmal mastitis in dairy herds. Vet. Clin. N. Am. Food A, v.19, p.199-221, 2003.

GONZÁLEZ, Y.R.C.; BASCUÑANA, C.R.; BÖLSKE, G. et al. In vitro amplification of the 16s rRNA genes from Mycoplasma bovis and Mycoplasma agalactiae by PCR. Vet Microbiol., v.47, p.183-190, 1995.

HARASAWA, R. PCR: application of nested PCR to detection of mycoplasmas. Mol. Diagn. Proc. Mycoplasmol., v.2, p.75-79, 1996.

HOUSE, J.; SHEEHY, P.; BOSWARD, K.; GUNN, A. Mycoplasma: a re-emerging pathogen. IN: COUNTDOWN SYMPOSIUM MELBOURNE, 27., 2011, Melbourne. Proceedings... Melbourne: [s.n.], 2011. v.401, p.23-400.
KIRK, J.H.; LAUERMAN, L.H.; ROBERTS, C.S. Mycoplasma mastitis in dairy cows. Compend. Contin. Educ. Vet., v.16, p.541-552, 1994.

LABORATORY handbook on bovine mastitis. Madison, WI: National Mastitis Council, 1999.

MCCLUSKEY, B.J.; LOMBARD, J.E.; HIRST, H. Mycoplasma in bulk tank milk on US dairy operations. IN: INTERNATIONAL SYMPOSIUM FOR VETERINARY EPIDEMIOLOGY AND ECONOMICS, 10., 2003, Vina del Mar. Proceedings..., Vina del Mar, Chile: [NZVA], 2003.

METTIFOGO, E.; NASCIMENTO, E.R.; MÜLLER, E.E.; NASCIMENTO, M.G.F.; FREITAS, J.C. Mastite bovina por Mycoplasma bovis. Rev. Bras. Med. Vet., v.18, p.22-25, 1996.

NICHOLAS, R.A.J.; FOX, L.K.; LYSNYANSKY, I. Mycoplasma mastitis in cattle: to cull or not to cull. Vet. J., v.216, p.142147, 2016.

OWENS, W.E.; NIPPER, W.A. Case study: development of a Mycoplasma mastitis control program in Louisiana. Prof. Anim. Sci., v.24, p.103-106, 2008.

PASSCHYN, P.; PIEPERS, S.; MEULEMEESTER, L. et al. Research in veterinary science betweenherd prevalence of Mycoplasma bovis in bulk milk in Flanders, Belgium. Res. Vet. Sci., v.92, p.219-220, 2012.

PRETTO, L.G.; MULLER, E.E.; FREITAS, J.C. et al. Mastite bovina por Mycoplasma bovis em rebanhos leiteiros. Pesqui. Vet. Bras., v.21, p.143-145, 2001.

SCHALM, O.W.; NOORLANDER, D.O. Experimental and observation leading to development of California mastitis test. J. Am. Vet. Med. Assoc., v.139, p.199-204, 1957.

VAN KUPPEVELD, F.J.; VAN DER LOGT, J.T.; ANGULO, A.F. et al. Genus-and speciesspecific identification of mycoplasmas by $16 \mathrm{~S}$ rRNA amplification. Appl. Environ. Microbiol., v.58, p.2606-2615, 1992. 